\title{
Children's science learning outside school: Parental support
}

\author{
Rahime Çobanoğlu \\ Sinop University, Faculty of Education, Sinop, Turkey, crahime@ gmail.com \\ Gülfem Dilek Yurttaş-Kumlu \\ Sinop University, Faculty of Education, Sinop, Turkey, gdyurttas@gmail.com
}

\begin{abstract}
This study examined (a) the availability of basic science materials in children's home environment, (b) the frequency of parents' involvement in informal science activities with their children, (c) the level of opportunities parents offered their children for learning basic science subjects, and (d) the effect of grade level on parental support for children's science learning. In this cross-sectional survey study, data were collected from 735 parents in a city in the north region of Turkey. Results revealed that most children did not have basic science materials at home. Parental support for making science trips was especially low. The parents supported their children's learning most in the area of health, security, and nutrition. The MANOVA results indicated that the parents of middle school children supported their children significantly less to do science and nature activities compared to the parents of preschool and elementary school children. The middle school children were also less likely to be supported by their parents to learn science subjects related to matter, energy, and livings compared to preschool children. The parents of preschool children offered more opportunities for their children to learn science subjects related to sky compared to the parents of elementary and middle school children.
\end{abstract}

Keywords: $\quad$ Parental support, Science learning, Science outside school

\section{Çocukların okul dışı fen öğrenmeleri: Aile desteği}

ÖZ Bu çalışmada (a) basit fen materyallerinin çocukların ev ortamında bulunup bulunmadığı, (b) ailelerin çocuklarıyla birlikte informal fen etkinliklerine katılım sıklığı, (c) temel fen konularını öğrenmeleri için ailelerin çocuklarına sundukları firsatların düzeyi ve (d) çocukların öğretim düzeyinin ailelerin fen öğrenmeleri için çocuklarına sağladıkları destek üzerindeki etkisi araştırılmıştır. Bu kesitsel tarama çalışmasında veriler, Türkiye'nin kuzey bölgesindeki bir ilde yaşayan 735 veliden toplanmıştır. Bulgular çocukların çoğunluğunun ev ortamında temel fen materyallerine sahip olmadıklarını göstermiştir. Özellikle bilim gezilerine katılmaya ilişkin olarak ailelerin çocuklarını destekleme düzeyi düşük bulunmuştur. Ailelerin çocuklarını en çok sağlık, güvenlik ve beslenme konularını öğrenmeleri için destekledikleri belirlenmiştir. MANOVA sonuçları, okul öncesi ve ilkokul çocuklarının ailelerine kıyasla ortaokul çocuklarının ailelerinin doğa ve bilim etkinlikleri yapma boyutunda çocuklarını önemli ölçüde daha düşük düzeyde desteklediklerini ortaya koymuştur. Ayrıca, okul öncesi çocukları ile karşılaştırıldıklarında ortaokul çocuklarının madde, enerji ve canlılar ile ilgili fen konularını öğrenmeleri için aileleri tarafından daha düşük düzeyde desteklendikleri saptanmıştır. İlkokul ve ortaokul çocuğu olan ailelere kıyasla okul öncesi çocuğu olan ailelerin gökyüzü ile ilgili fen konularını öğrenmelerine yönelik çocuklarına daha çok firsat sundukları tespit edilmiştir.

Anahtar Sözcükler: $\quad$ Aile desteği, Fen öğrenme, Okul dışında fen

Citation: $\quad$ Çobanoğlu, R., \& Yurttaş-Kumlu, G. D. (2020). Children's science learning outside school: Parental support. Turkish Journal of Education, 9(1), 46-63. DOI: 10.19128/turje.613091 


\section{INTRODUCTION}

All children, regardless of their future career fields, should construct a basic knowledge of science to involve in science-related public discussions, critically evaluate scientific information concerning their lives, and continue lifelong science learning (National Research Council, 2012). Conventionally, schools have been held accountable for teaching science; however, Korpan, Bisanz, Bisanz, Boehme, and Lynch (1997) question if schools are the main source for developing children's science literacy. Korpan et al. (1997) mainly argue that in communities where science instruction is confined to two hours in schools, children engage in a range of activities that helps them learn science outside schools such as watching television programs, reading books with their parents, participating in communitybased programs, making observations, and doing experiments. Gelmez-Burakgazi and Yildirim (2014) also assert that children receive support from several informal sources such as internet, science magazines, and television to develop their science literacy. In a more recent study, Rosenthal (2018) shows that one third of the sample uses Youtube to watch science videos for learning science in their free times.

Informal science learning, basically defined as science learning outside traditional formal schooling, is based on the assumption that learning is not the product of a single experience but occurs over time through the accumulation of various experiences (Dierking, Falk, Rennie, Anderson, \& Ellenbogen, 2003). Maarschalk (1988) states that informal education, the education through the experiences in family and neighborhood, is both a condition and outcome for scientific literacy. Informal learning sources and experiences outside school can improve children's scientific reasoning abilities (Falk \& Dierking, 2010; Gerber, Cavallo, \& Marek, 2001; Şentürk, 2015), knowledge and understanding in science (Fenichel \& Schweingruber, 2010), and motivation to learn science (Goto, Nakanishi, \& Kano, 2018). As science instruction in classroom environments is mostly rigid and based on presentations, learning science through informal sources, which offers a more relaxing and friendly learning context (Jones, 1997; Kim \& Dopico, 2016), can be more effective for some students. Thus, we must endeavor to blend formal experiences with informal experiences (Coll \& Coll, 2018; Hofstein \& Rosenfeld, 1996; Sun \& Looi, 2018) for effective science education.

The current study addresses one of the significant informal science learning sources for children: Parents. Parents constitute one of the contexts where children can observe and understand nature (Eberbach \& Crowley, 2017). Today, it is widely recognized that schools need the support of families to maximize children's benefits from schooling (Bronfenbrenner, 1994; Çelenk, 2003; Dabney, Chakrverty, \& Tai, 2013; Desforges \& Abouchaar, 2003; Epstein \& Dauber, 1991; Gonzalez, Borders, Hines, Villalba, \& Henderson, 2013; Keçeli-Kaysili, 2008). Parents can support the education of their children in different ways. For instance, "school-like families" primarily view their child as a student and care about their school activities for improving their child's achievement and skills (Epstein, 2010). Through creating a positive "academic home climate", as defined by Campbell and Verna (2007), parents can cultivate behaviors, attitudes, beliefs, and values that assist children in having higher levels of achievement. Parents can participate in school activities at school and as well support children's learning at home (Epstein \& Dauber, 1991).

Regarding science education, parents can offer opportunities for their children to facilitate their learning of science topics outside school. They can facilitate their children's learning as they offer various science-related materials at home and engage in informal science activities with their children such as visiting science museums/zoos, participating in science camps/clubs, and being in nature (Lin \& Schunn, 2016). Hall and Schaverien (2001) indicated that families' participation in children's scientific and technological inquiries at home had educational significance. Dierking and Falk (1994) 
in their review study showed that family visits to informal science settings such as exhibits were vital for children's science education. Crowley and Callanan (1998) revealed that parents shaped children's scientific thinking during a museum visit as their interactions with children broadened and deepened their child's experience. De Lurdes Cardoso (2002) demonstrated that children were more actively involved and talked more freely in home-based science activities. Harris and Winterbottom (2018) observed that there was a relatively high level of conceptual and emotional talk between families and children during a gallery visit, and the families as the scaffolders facilitated their children's learning in these settings. In a more recent study, Vandermaas-Peeler, Mischka, and Sands (2019) noticed that parents were able to enhance their preschool children's science and mathematics learning and could support their children's reasoning better if the professionals encouraged and trained them regarding how to guide children's inquiry at home. Dou, Hazari, Dabney, Sonnert, and Sadler (2019), moreover, noted that talking about science with families and also friends during K-4 years was associated with individuals' seeing themselves as a STEM (science, technology, engineering, and mathematics) person in college. The above results clearly imply that parental support is one of the factors that warrants the attention of practitioners, educational researchers, and policy makers for improving children's science learning.

\section{The Present Study}

The current research seeks to investigate the parental support for children's science learning outside school. We pay attention to the three aspects of parental support in this paper: (a) the availability of basic science materials that can support children's science learning in their home environment, (b) the frequency of parents' involvement in informal science activities with their children, and (c) the level of opportunities parents offer their children for learning basic science subjects. Additionally, the study examines the parental support for children's science learning in three different grade levels including preschool, elementary school (Grades 1-4), and middle school (Grades 5-8) considering that children's age can predict parents' engagement in children's education (Oswald, Zaidi, Cheatham, \& Brody, 2018).

This study is considered important mainly for three reasons. Firstly, children's science learning outside school constitutes an opportunity for effective science education; however, it has been investigated less in educational research compared to children's science learning at schools (Fraser \& Kahle, 2007; Gerber, Marek, \& Cavallo, 2001; Salmi, Thuneberg, \& Vainikainen, 2017). To the best of our knowledge, there is a dearth of studies in literature on parental support regarding children's learning of science out of school contexts (e.g., Alexander, Johnson, \& Kelley, 2012; Korpan et al., 1997; Renninger \& Hidi, 2011). In his review study on informal science learning in the context of Turkey, Saraç (2017) as well demonstrates that the existing studies on informal learning environments in Turkey have been mostly carried out with middle school children and teachers, and have extensively focused on learning in museums, science centers, and field trips, whereas little is known regarding parental support for children's learning at home and outside home. The current study with its focus on parents as an informal learning source is likely to address a gap in the national literature. Secondly, this initial explorative research could contribute to the identification and discussion of needs regarding parental support for children's science learning. Results could offer implications for practitioners and policy makers for guiding parents to nurture the science learning of their children at different grade levels. Lastly, the study could inform researchers regarding the factors that need to be investigated in-depth in future research regarding parental support in science education. 


\section{METHODOLOGY}

In this quantitative study, the cross-sectional survey method was applied to examine the opportunities parents offer their children of three different grade levels for science learning outside schools. In cross-sectional surveys, data are gathered one point in a time (Fraenkel, Wallen, \& Hyun, 2012).

\section{Sample}

This study was conducted in a non-metropolitan city in the north region of Turkey. The sample involved the parents of preschool, elementary school and middle school children attending public schools. In Turkey, preschool education covers the education of children between the ages of 3 and 5 . Elementary school children are between the ages of 6 and 10 and attend the grades between 1 and 4 . The middle school level comprises the grades between 5 and 8 for children between the ages of 11 and 14. Cluster random sampling method was implemented in the selection of parents. In this sampling method, groups rather than individuals are selected because researchers do not have access to a complete list of the population (Fraenkel et al., 2012). In the selection of the sample, two steps were taken. In the first step, schools were selected to reach parents. As there are not many public preprimary schools in the city, all pre-primary schools in the central districts $(n=3)$ were included in the sample. Moreover, six schools from the population of 14 public elementary schools and four schools from the population of 8 public middle schools were selected. Especially, the schools which included a higher number of students and located in urban and rural parts of the central area were involved in the sample. In the second step, two classes were randomly selected in the selected schools for each grade level. The survey forms were distributed to children in these classes to deliver them to their parents. In total, the forms were sent to 1392 parents in this study. Of these parents, 735 completed the survey form, corresponding to a response rate of $52.8 \%$.

Table 1.

Characteristics of the sample $(N=735)$

\begin{tabular}{lrr}
\hline Variable & $n$ & $\%$ \\
\hline Respondent & & \\
Mother & 457 & 62.2 \\
$\quad$ Father & 243 & 33.1 \\
Educational level of the respondent & 149 & 20.3 \\
$\quad$ Elementary and below & 106 & 14.4 \\
Middle school & 181 & 24.6 \\
High school & 291 & 39.6 \\
Higher education & 30 & 4.1 \\
Perceived self-efficacy for answering children's questions about science & & \\
No at all & 170 & 23.1 \\
Slightly & 415 & 56.5 \\
Moderately & 64 & 8.7 \\
$\quad$ Very & 40 & 5.4 \\
A great deal & & \\
Grade level of children & 99 & 13.5 \\
Preschool education & 395 & 53.7 \\
Elementary school & 241 & 32.8 \\
Middle school & & \\
\hline
\end{tabular}

Table 1 displays the general characteristics of 735 parents involved in the current study. As shown in Table $1,53.7 \%$ of the parents $(n=395)$ had elementary school children, $32.8 \%$ of the parents $(n=$ $241)$ had middle school children, and $13.5 \%$ of the parents $(n=99)$ had preschool children. In the sample, the respondents were mostly the mothers of children (62.2\%). The parents had various degrees of education in this study. Specifically, 39.6\% had a higher education degree, whereas $20.3 \%$ had an 
elementary education degree or below. More than half of the participants (56.5\%) perceived themselves moderately efficacious to answer their children's questions about science.

\section{Data Collection Tools}

Data were collected through a parent questionnaire developed for the current study. The studies by Alexander et al. (2012), Olgan (2015), National Research Council (2012), and Saçkes (2014) guided the item development phase for the parent questionnaire. The questionnaire was reviewed by two science education experts, two curriculum specialists, and six parents with various educational degrees, and revised based on their feedback. The parent questionnaire is composed of the following three parts:

Science Materials at Home Questionnaire (SMHQ). SMHQ examines if specific 13 materials (e.g., magnifier, thermometer, and compass) that can support children's science learning are available in their home environment. The responses of the participants are received as Yes or No.

Parental Support for Informal Science Activities Questionnaire (PS-ISAQ). The PS-ISAQ intends to measure to what extent parents offer their children opportunities for involving in basic informal science activities based on a 5-point response scale (1: Never, 5: A great deal). This questionnaire addresses the parental support for thirteen informal science activities such as reading science-related books/ magazines, visiting a science museum, and making observation.

The PS-ISAQ was tested with 273 parents in a pilot study. The principal component analysis results showed that the scale was composed of three components, explaining $59.76 \%$ of the variance in the sample. The component loadings were all above the cut-off criteria of .32. The first component is Using Sources, which includes five items regarding the opportunities parents offer their children to use sources (e.g., book, video, experts) to learn science. The second component is Making Science Trips, which involves three items concerning the opportunities parents offer their children to participate in science trips. The third component, named as Doing Science and Nature Activities, is composed of five items and deals with the opportunities parents offer their children to engage in activities in which they actively do science and be in nature such as talking about science subjects, making observation, doing basic experiments, and participating in nature walk.

Confirmatory factor analysis (CFA) was performed to confirm the three-component structure for the PS-ISAQ for the sample used in this study. The CFA results indicated that the proposed model had a good fit to the data (Satorra-Bentler $\chi^{2}(62)=333.73$, RMSEA $=.08$, CFI $=.96$, TLI $=.95$, SRMR $=$ .06). The component loadings were all statistically significant. The items on each dimension were internally consistent. The Cronbach's alpha values were .80 for Using Sources, .73 for Making Science Trips, and .78 for Doing Science and Nature Activities.

Parental Support for Children's Learning of Science Subjects Questionnaire (PS-CLSSQ). The PSCLSSQ aims to assess to what extent parents offer their children opportunities for learning basic science subjects based on a 5-point response scale (1: Never, 5: A great deal). The PS-CLSSQ inquiries into the parental support for seventeen science subjects such as motion, rock and soils, and seasons.

The PS-CLSSQ was subjected to the principal component analysis with a sample of 257 parents in the pilot study. The analysis revealed that two components best explained the structure of the PS-CLSSQ. In this model, the loadings of the seventeen items were all above the cut-off value of .32. The twocomponent model overall explained 59.84\% of the variance in the sample. As the twelve items on the first component are about the opportunities parents offer their children to learn science subjects related matter, energy, and livings (e.g., rock and soil, heat and temperature, human body), this component is named as Matter, Energy, and Livings. The five items on the second component concern the 
opportunities parents offer their children to learn science subjects related to sky (e.g., celestial objects, day and night) and thus this component is entitled as $S k y$.

The CFA was performed to test the two-component structure for the PS-CLSSQ in the current sample. The initial results indicated that the model needed improvement (Satorra-Bentler $\chi^{2}(118)=867.80$, RMSEA $=.10, \mathrm{CFI}=.96$, TLI $=.96$, SRMR $=.06$ ). Considering the modification indices and the content of items, the error covariances of the three pairs of items were set to be free in the model. These changes yielded an improved and acceptable model fit (Satorra-Bentler corrected $\chi^{2}(115)=$ $589.41, \mathrm{RMSEA}=.08, \mathrm{CFI}=.98, \mathrm{TLI}=.97, \mathrm{SRMR}=.05)$. The factor loadings were all statistically significant. The Cronbach alpha values presented evidence for the internal consistency of the items on the two dimensions (.92 for Matter, Energy, and Livings; .89 for Sky).

\section{Data Collection Process}

The permissions were obtained from the Human Subjects Ethics Committee and the Provincial Directorate of National Education (Dated 07.02.2018 and No. 25072426-730.08.03-E.2583604) for data collection. We cooperated with the selected schools to contact with parents in the data collection process of the study.

\section{Data Analysis}

Data set was preliminarily screened for the incomplete values. The missing scores were less than $1 \%$ for each variable. As there were a few missing values, the multiple imputation with expectationmaximization algorithm was performed with the LISREL software. There was not any significant difference between the means obtained from the data set with missing values and those obtained from the data set with imputed values. As a result, the imputed data set was used in data analysis. The two questionnaires (i.e., PS-ISAQ and PS-CLSSQ) were subjected to the principal component analysis. Principal component analysis helps to reduce data to a manageable size (Field, 2009). The direct oblimin method was used for rotation because there was correlation among the components. The Kaiser-Meyer-Olkin value exceeded the recommended value of .70 (Field, 2009) for both PS-ISAQ and PS-CLSSQ. The component loadings were interpreted significant when they were .32 and greater (Tabachnick \& Fidell, 2013). Confirmatory factor analyses (CFA) were also conducted for the PSISAQ and PS-CLSSQ with the LISREL software. The robust maximum likelihood method was selected in the estimation of parameters because multivariate normality was not met in the sample. The model fit was evaluated based on the multiple goodness-of-fit statistics. Specifically, a model is considered acceptable if RMSEA is .08 and less, TLI and CFI is .95 or greater, and SRMR is .10 or less (Schermelleh-Engel, Moosbrugger, \& Müller, 2003).

Descriptive analysis and one-way multivariate analysis of variance (MANOVA) were performed to address the research questions in the present study. The inspection of normal Q-Q plots, histograms, as well as the skewness and kurtosis scores presented evidence regarding the normality of the distribution of scores in the sample. Mardia's test result showed a deviation of the multivariate normality in the data. However, this result was neglected because the violation of the multivariate normality assumption does not create severe problems with moderate sample sizes (Hair, Black, Babin, \& Anderson, 2010). Two separate one-way MANOVAs were performed to examine the effect of children's grade level on the two aspects of parental support for children's science learning: parents' involvement in informal science activities with their children and the opportunities parents offer their children for learning basic science subjects. Each group should include at least 20 members for conducting MANOVA (Hair et al., 2010) and this condition was met in the current study. The Box's and Levene's tests evidenced that the assumptions of homogeneity of variance-covariance matrices and equality of variance were met. Bonferroni adjustment was applied in the interpretation of the tests of between-subjects effects to eliminate Type 1 error. The Scheffe post-hoc method was adopted to examine pairwise group differences because this method is considered appropriate for comparison when group sizes are not equal (Ruxton \& Beauchamp, 2008). 


\section{RESULTS}

\section{The Availability of Basic Science Materials in Children's Home Environment}

Table 2 presents the descriptive statistics regarding the existence of science materials that can support children's science learning in their home environment as reported by their parents.

Table 2.

Availability of science materials in children's home environment

\begin{tabular}{|c|c|c|c|c|c|c|c|c|}
\hline \multirow[t]{2}{*}{ Science material } & \multicolumn{2}{|c|}{ Preschool } & \multicolumn{2}{|c|}{$\begin{array}{l}\text { Elementary } \\
\text { school }\end{array}$} & \multicolumn{2}{|c|}{$\begin{array}{l}\text { Middle } \\
\text { school }\end{array}$} & \multicolumn{2}{|c|}{$\begin{array}{l}\text { Total } \\
\text { group }\end{array}$} \\
\hline & $n$ & $\%$ & $n$ & $\%$ & $n$ & $\%$ & $n$ & $\%$ \\
\hline Magnifier & 33 & 38.8 & 125 & 35.8 & 87 & 39.2 & 245 & 37.3 \\
\hline Microscope & 7 & 8.2 & 14 & 4 & 5 & 2.3 & 26 & 4 \\
\hline Telescope & 4 & 4.7 & 11 & 3.2 & 3 & 1.4 & 18 & 2.7 \\
\hline Binoculars & 27 & 31.8 & 92 & 26.4 & 71 & 32 & 190 & 29 \\
\hline Compass & 30 & 35.3 & 135 & 38.7 & 90 & 40.5 & 255 & 38.9 \\
\hline Thermometer & 54 & 63.5 & 190 & 54.4 & 119 & 53.6 & 363 & 55.3 \\
\hline Toy Magnet & 61 & 71.8 & 223 & 63.9 & 149 & 67.1 & 433 & 66 \\
\hline Toy electric circuits & 19 & 22.4 & 78 & 22.3 & 76 & 34.2 & 173 & 26.4 \\
\hline Science-related printed materials (e.g., book, poster) & 46 & 54.1 & 190 & 54.4 & 136 & 61.3 & 372 & 56.7 \\
\hline Model (e.g., earth model, human body model) & 21 & 24.7 & 102 & 29.2 & 56 & 25.2 & 179 & 27.3 \\
\hline $\begin{array}{l}\text { Science kits with basic experiments (e.g., electricity kit, botanic kit, } \\
\text { chemistry kit) }\end{array}$ & 13 & 15.3 & 45 & 12.9 & 47 & 21.2 & 105 & 16 \\
\hline Science-related computer applications (e.g., games, animations) & 31 & 36.5 & 144 & 41.3 & 115 & 51.8 & 290 & 44.2 \\
\hline Collections of natural materials & 39 & 45.9 & 134 & 38.4 & 87 & 39.2 & 260 & 39.6 \\
\hline
\end{tabular}

The material preschool, elementary school and middle school children were most likely to have in their home environment was similarly toy magnets $(71.8 \%$ for preschool, $63.9 \%$ for elementary school, $67.1 \%$ for middle school). More than $50 \%$ of the preschool, middle school and elementary school children had a thermometer $(63.5 \%$ for preschool, $54.4 \%$ for elementary school, $53.6 \%$ for middle school) and science-related printed materials $(54.1 \%$ for preschool, $54.4 \%$ for elementary school, $61.3 \%$ for middle school) at their home. More than half of the middle school children (51.8\%) had access to science-related computer applications at home unlike preschool (36.5\%) and elementary school (41.3\%) children. The material preschool, elementary school and middle school children were least likely to have at their home was likewise telescope (4.7\% for preschool, 3.2\% for elementary school, $1.4 \%$ for middle school). Additionally, the parental reports indicated that more than $50 \%$ of the children across the three grade levels did not have a magnifier, binocular, compass, toy electric circuit, model, science kit, and collection of natural materials at their home.

\section{The Frequency of Parents' Involvement in Informal Science Activities with Their Children}

Table 3 presents the frequency of the parents' involvement in informal science activities with their children. The results revealed that children across the three grade levels were similarly least likely to have opportunities to involve in science trips with their parents. The mean values in this dimension were below 2 on the 5-point response scale for each grade level ( $M=1.92, S D=0.80$ for preschool, $M$ $=1.95, S D=0.75$ for elementary school, $M=1.91, S D=0.82$ for middle school). As regards parental support for children's use of sources to learn science, the mean scores were approaching to 3 in each grade level on the 5-point response scale $(M=2.75, S D=0.79$ for preschool, $M=2.77, S D=0.81$ for elementary school, $M=2.86, S D=0.76$ for middle school). In relation to the opportunities parents offer their children for doing science and nature activities, the mean value was close to 3 for the parents of middle school children $(M=2.78, S D=0.85)$, while the average scores were slightly exceeding 3 for the parents of preschool and elementary school children $(M=3.21, S D=0.70$ for 
preschool, $M=3.03, S D=0.83$ for elementary school). For the preschool and elementary school children, the level of parental support for children's doing science and nature activities was higher than the level of parental support for children's use sources to learn science. Yet the parents of middle school children seemed to offer their children slightly more opportunities to using sources than doing science and nature activities.

Table 3.

The frequency of the parents' involvement in informal science activities with their children

\begin{tabular}{lccccccc}
\hline & \multirow{2}{*}{$\begin{array}{c}\text { Preschool } \\
\text { Informal science activity }\end{array}$} & \multicolumn{2}{c}{$\begin{array}{c}\text { Elementary } \\
\text { school }\end{array}$} & \multicolumn{2}{c}{$\begin{array}{c}\text { Middle } \\
\text { school }\end{array}$} & \multicolumn{2}{c}{ Total } \\
group
\end{tabular}

Considering thirteen informal science activities examined in the current study, the lowest mean score was obtained for visiting a science fair/festival across the three grade levels $(M=1.60, S D=0.83$ for preschool, $M=1.60, S D=0.87$ for elementary school, $M=1.69, S D=0.96$ for middle school, $M=$ $1.62, S D=0.89$ for total group). However, the activity parents offered their children most frequently varied by grade level. For the preschool group, the activity with the highest mean score was talking with children about science subjects which are part of their daily lives $(M=3.63, S D=0.79)$. For the group of elementary school, parents reported that they offered their children the highest level of support for collecting various materials from nature $(M=3.44, S D=1.20)$. On the other side, the parents of the middle school children supported their child most in doing research about a question their child was curious about $(M=3.50, S D=1.05)$.

\section{The Level of Opportunities Parents Offer Their Children for Learning Basic Science Subjects}

Table 4 displays the level of opportunities parents offer their children to learn basic science subjects related to two dimensions: matter-energy-livings and sky. The total group mean scores for both dimensions were nearly 3 on the 5 -point response scale $(M=3.02, S D=0.83$ for subjects related to matter, energy, and livings, $M=2.96, S D=0.96$ for subjects related to sky). As regards the level of opportunities parents offered their children to learn subjects related to matter, energy, and livings, the mean score was slightly exceeding 3 for the parents of preschool $(M=3.25, S D=0.76)$ and elementary school children $(M=3.02, S D=0.81)$ on the 5-point response scale. The mean score of this dimension was slightly less than 3 for the middle school group $(M=2.91, S D=0.87)$. The level of opportunities parents offered their preschool children to learn subjects related to sky was on average above 3 on the 5-point response scale $(M=3.30, S D=0.91)$. Yet for the elementary and middle school grade levels, the mean value for the parental support for children's learning of subjects related to sky was slightly below 3 on the 5-point response scale $(M=2.95, S D=0.96$ for elementary school, $M=$ 2.83, $S D=0.96$ for middle school). The means for both dimensions were higher for preschool group compared to the elementary and middle school groups. 
Table 4.

The level of opportunities parents offer their children for learning basic science subjects

\begin{tabular}{|c|c|c|c|c|c|c|c|c|}
\hline \multirow[t]{2}{*}{ Science subject } & \multicolumn{2}{|c|}{ Preschool } & \multicolumn{2}{|c|}{$\begin{array}{c}\text { Elementary } \\
\text { school }\end{array}$} & \multicolumn{2}{|c|}{$\begin{array}{l}\text { Middle } \\
\text { school }\end{array}$} & \multicolumn{2}{|c|}{ Total group } \\
\hline & $M$ & $S D$ & $M$ & $S D$ & $M$ & $S D$ & $M$ & $S D$ \\
\hline Matter-Energy-Livings & 3.25 & 0.76 & 3.02 & 0.81 & 2.91 & 0.87 & 3.02 & 0.83 \\
\hline Properties of matters in nature & 2.98 & 1.08 & 2.99 & 1.10 & 2.89 & 1.16 & 2.95 & 1.11 \\
\hline Motion & 3.42 & 1.03 & 3.19 & 1.14 & 3.02 & 1.21 & 3.16 & 1.15 \\
\hline Light and shadow & 3.20 & 0.95 & 2.77 & 1.05 & 2.65 & 1.13 & 2.78 & 1.08 \\
\hline Sound & 3.28 & 1.02 & 2.94 & 1.10 & 2.87 & 1.24 & 2.96 & 1.14 \\
\hline Heat and temperature & 3.04 & 1.10 & 2.89 & 1.07 & 2.91 & 1.12 & 2.92 & 1.09 \\
\hline Electricity & 2.67 & 1.14 & 2.57 & 1.16 & 2.65 & 1.16 & 2.61 & 1.15 \\
\hline Magnets & 2.78 & 1.06 & 2.70 & 1.14 & 2.70 & 1.26 & 2.71 & 1.17 \\
\hline Plants and animals & 3.58 & 0.98 & 3.32 & 1.15 & 3.20 & 1.16 & 3.31 & 1.13 \\
\hline Human body & 3.39 & 1.02 & 3.09 & 1.15 & 2.83 & 1.21 & 3.04 & 1.17 \\
\hline Health, security, nutrition & 3.89 & 0.91 & 3.58 & 1.07 & 3.48 & 1.10 & 3.59 & 1.96 \\
\hline Rock and soil & 3.31 & 1.18 & 3.09 & 1.18 & 2.67 & 1.25 & 2.98 & 1.22 \\
\hline Water & 3.48 & 1.06 & 3.19 & 1.21 & 3.05 & 1.29 & 3.19 & 1.23 \\
\hline Sky & 3.30 & 0.91 & 2.95 & 0.96 & 2.83 & 0.96 & 2.96 & 0.96 \\
\hline Celestial objects (sun, moon, stars) & 3.28 & 1.10 & 2.81 & 1.25 & 2.63 & 1.22 & 2.81 & 1.23 \\
\hline Solar system and space & 2.92 & 1.14 & 2.45 & 1.24 & 2.47 & 1.19 & 2.52 & 1.22 \\
\hline Day and night & 3.30 & 1.05 & 2.88 & 1.18 & 2.75 & 1.24 & 2.89 & 1.20 \\
\hline Seasons & 3.44 & 1.01 & 3.23 & 1.06 & 3.05 & 1.21 & 3.20 & 1.12 \\
\hline Weather condition & 3.53 & 1.03 & 3.37 & 1.06 & 3.25 & 1.23 & 3.35 & 1.12 \\
\hline
\end{tabular}

Considering seventeen basic science subjects specified in the present study, preschool, elementary and middle school children were similarly supported most by their parents in the area of health, security, and nutrition $(M=3.89, S D=0.91$ for preschool, $M=3.58, S D=1.07$ for elementary school; $M=$ $3.48, S D=1.10$ for middle school; $M=3.59, S D=1.96$ for total group). Plants and animals, and weather condition were the two subjects that were supported more compared other basic subjects in each grade level. The science subject for which parents offered their children least opportunity for learning was electricity in the preschool group $(M=2.67, S D=1.14)$, while the science subject parents were least likely to support was solar system and space for elementary $(M=2.45, S D=1.24)$ and middle school groups $(M=2.47, S D=1.19)$.

\section{The Effect of the Grade Level on Parental Support for Children's Science Learning}

The first MANOVA results indicated that there was a significant effect of children's grade level on the linear combination of the three dependent variables regarding the frequency of the parents' involvement in informal science activities with their children: $F(6,1404)=2737.65, p=.000$; Wilks' Lambda $=.93$. The partial eta squared result showed that the grade level explained $4 \%$ of the variance in the sample. When the effect of the grade level for the three dependent variables was examined separately, the results demonstrated that the grade level significantly influenced the level of opportunities parents offered their children for doing science and nature activities $(F(2,704)=$ $10.999, p=.000$, partial eta squared $=.03$ ). Yet the grade level did not have any significant effect on the level of the opportunities parents offered their children for using sources to learn science and making science trips. The multiple comparisons with the Scheffe post hoc method showed a significant difference between the parents of preschool and middle school children and between the parents of elementary and middle school children. The parents of the middle school children offered significantly less opportunities for their children to do science and nature activities compared to the parents of preschool and elementary school children.

The second MANOVA results indicated that the grade level of children significantly influenced the combined dependent variables related to the extent of the opportunities parents offered their children for learning basic science subjects: $F(4,1340)=3.952, p=.003$; Wilks' Lambda $=.98$. Given the partial eta squared result, the grade level explained $1 \%$ of the variance in the sample. The effect of the 
grade level was significant for both dependent variables: $F(2,671)=5.434, p=.005$, partial eta squared $=.02$ for parental support for science subjects related to matter, energy, and livings; $F(2,671)$ $=7.518, p=.001$, partial eta squared $=.02$ for parental support for science subjects related to sky. The multiple comparisons with the Scheffe post hoc procedure showed that there was a significant difference between the parents of the preschool and middle school children regarding the level of opportunities they offered their children to learn basic science subjects related to matter, energy, and livings. Moreover, the parents of preschool children were significantly different from the parents of elementary and middle school children regarding the level of opportunities they offered their children to learn basic science subjects related to sky. The results demonstrated that the parents of preschool children offered significantly more opportunities for their children to learn science subjects related to matter, energy, and livings than the parents of middle school children. In addition, parental support for learning science subjects related to sky was significantly higher for preschool children compared to elementary and middle school children.

\section{DISCUSSION}

The present study attempted to examine the informal science learning opportunities parents offered their preschool, elementary school and middle school children in the context of Turkey. The study presents four main findings that warrant discussion.

First, results indicated that most children across the three grade levels (i.e., preschool, elementary school, middle school) had limited access to a range of materials that could support their science learning in their home environment. Telescope and microscope, emerged as the two materials unavailable in most of children's home, might not be affordable for most parents. On the other hand, it should be noted that some cheap materials which can be easily supplied by parents such as a magnifier, binocular, compass, and natural materials were not also present in majority of the homes in the study. The inexistence of various science materials in children's home environments is viewed as a limitation for children's science learning given that the materials at home play an important role in stimulating children for engaging in informal scientific inquiries (Sha, Schunn, Bathgate, \& BenEliyahu, 2016; Worth, 2010).

Second, this study revealed that parents did not often provide their children with opportunities to involve in informal science activities despite the existing evidence regarding parental contributions to children's learning during informal science activities (e.g., Crowley \& Callanan, 1998; De Lurdes Cardoso, 2002; Halim, Abd Rahman, Zamri, \& Mohtar, 2018; Harris \& Winterbottom, 2018; Vandermaas-Peeler et al., 2019). Several informal science activities that parents could perform in everyday life with their children (e.g., reading science books, watching science videos/films, talking with children about science subjects, making observations) occurred roughly at a moderate level in the present sample. This result aligns with previous research showing that parental support at home for children's learning occurred at a medium level in Turkey (e.g. Aksu \& Karaçöp, 2015; Çağdaş, Özel, \& Konca, 2016). Importantly, the current results highlighted that most children regardless of their grade level were not involved in science trips by their parents. This finding might be because there is not currently a science museum, zoo, or any other science area to visit in the city where this study was conducted. In addition, it is worthy to mention that science fairs/festivals are often organized as school events which do not require parental involvement in the city.

Third, the level of opportunities parents offered their children to learn basic science subjects was overall moderate in the present study. The study indicated that parents offered their children more learning opportunities for specific science subjects. Considering the subjects supported most in each grade level (i.e., health, security, and nutrition, plants and animals, and weather condition), it can be 
argued that the parents assisted their children more for learning science subjects that exerted a direct influence on their daily lives. In addition, parents might be more likely to support their children' learning for science subjects that they perceive to be easy to understand. It seems that the science subjects supported less by the parents in the current study (e.g., electricity, solar system and space) demand an advanced level of scientific understanding. It must be noted that the parents' level of selfefficacy for answering children's science-related questions was mostly moderate or below in the current sample. As stated by Lee and Nie (2015), the low self-efficacy for science can hinder parents from involving in their children's science education. Thus, it becomes critical that parents improve their own scientific understanding and efficacy to help their children learn basic science subjects.

Fourth and finally, there was evidence that the grade level significantly influenced the parental support for children's science learning outside school. The parents of middle school children did not support their children to do science and nature activities as much as the parents of preschool and elementary school children. Moreover, the preschool children obtained more support from their parents for learning science topics than the elementary and middle school children. These findings are likely to support that parent involvement in children's education decreases as child age increases (e.g., Green, Walker, Hoover-Dempsey, \& Sandler, 2007; Hornby \& Lafaele, 2011; Oswald et al., 2018). The lower levels of parental support in upper grades might be because of children's desire for greater independence as they get older (Green et al., 2007) as well as the lack of strong, positive, and comprehensive parent involvement programs for middle school grades (Epstein \& Dauber, 1991). Additionally, children's age might alter how parents engage in their children's education (Hurley, Lambert, January, \& D'Angelo, 2017). Boonk, Gijselaers, Ritzen, and Brand-Gruwel (2018) in their review study conclude that parent involvement does not decrease by children's age but occurs in different ways. Considering their argument, the current results might not necessarily show that the parents of the middle school children are less interested in involving in children's science learning. They might support the science learning of their children outside schools in ways which are not examined in the current study.

\section{CONCLUSION}

The present findings are likely to support the argument that the value of parent involvement in education has not been recognized yet in the context of Turkey (Keçeli-Kaysili, 2008; Özeke-Kocabaş, 2006) although involving parents in education has been a significant component of Turkish Education System especially since the education reform movement that took place in 2005 based on a constructivist way of teaching (Koc, Isiksal, \& Bulut, 2007). The low level of parental support for children's science learning outside school in Turkey might be because some Turkish parents (a) hold schools accountable for the education of their children, (b) are not conscious about how to involve in the education of their children, and (c) are not supported by teachers and school administrators to involve in educational processes (Erdoğan \& Demirkasımoğlu, 2010). Some Turkish parents might as well think that parent involvement is not necessary because they think that their child is already learning effectively and is a middle school student (Kasapoğlu, 2014).

If parents do not effectively support their children's science learning outside school, children's science education will be mostly restricted to formal school experiences. The current science education curriculum of Turkey also highlights the significance of science learning out of school environments (Ministry of National Education, 2018). To improve parental support for children's science learning outside school, parents' beliefs about their role in the education of their children, their sense of efficacy for supporting their children's learning, and their beliefs about the opinions of the child and school about their involvement need to be addressed (Hoover-Dempsey \& Sandler, 1997; Walker, Wilkins, Dallaire, Sandler, \& Hoover-Dempsey, 2005). We should awaken parents regarding the 
importance of their involvement in children's learning of science through informal ways (Lee \& Nie, 2015). For this end, teachers and schools should guide parents about what to do at home (Epstein, 1986; Hamlin \& Flessa, 2018; Leithwood \& Patrician, 2015), and establish well-designed programs of family and community partnerships (Epstein \& Salinas, 2004). These programs should especially help parents improve their perception of capabilities for supporting children's science learning and increase their interest in involving in their children's education (Kaya \& Lundeen, 2010). In these programs, it is also important to show parents that science is not necessarily a laboratory discipline that requires elaborate equipment but part of everyday life (Fleer, 1996).

\section{Limitations and Suggestions for Future Research}

This study has several limitations. For the external validity, it is important to replicate the current study with samples drawn from different regions of Turkey. The use of self-report data is a significant threat to the internal validity of the study. In this study, it is acknowledged that parents provide sincere responses rather than socially desirable answers. The triangulation of data sources could improve the validity of results; thus, future studies should examine how children and teachers evaluate parental support for science learning outside school. In the present study, the influence of the grade level on parental support for children's science learning was statistically significant but it is worthy to mention that this effect was not considered large based on Cohen's criteria (1988) (i.e., small $=.01$, medium $=$ .06 , large $=.14$ ). Future qualitative studies might help to identify the factors that exert a greater influence on parental support for children's science learning across different grades. There is also a need for cross-cultural research to scrutinize the cultural differences in how parents support the education of their children. Moreover, longitudinal studies should be conducted to examine how parental support for children's science learning changes as children grow. Future research should also shed light into the quality of learning opportunities for children because the outcomes of science learning outside school depend on the quality of parental support as well as its frequency. In this regard, we recommend that scholars pay attention to the quality of parent-child interactions during science learning experiences outside school. The current study addressed to what extent parents supported their children to learn basic science subjects rather than the means parents used for supporting their children's learning of different science topics. Therefore, it may be important to reveal how parents support their children's learning of various science topics in future research.

\section{Acknowledgement}

A part of this study was presented at the VI. International Congress on Curriculum and Instruction at Kars in Turkey. The study obtained the approval of the Ministry of National Education to collect data in schools (Dated 07.02.2018 and No. 25072426-730.08.03-E.2583604).

\section{REFERENCES}

Aksu, F. F., \& Karaçöp, A. (2015). Ev temelli fen öğrenme etkinliklerine aile katılımının bazı değişkenler açısından incelenmesi [An investigation of the parental involvement in home-based science learning activities in terms of some variables]. Bayburt Eğitim Fakültesi Dergisi, 10(1), 154-179.

Alexander, J. M., Johnson, K. E., \& Kelley, K. (2012). Longitudinal analysis of the relations between opportunities to learn about science and the development of interests related to science. Science Education, 96(5), 763-786. DOI: 10.1002/sce.21018

Boonk, L., Gijselaers, H. J. M., Ritzen, H., \& Brand-Gruwel, S. (2018). A review of the relationship between parental involvement indicators and academic achievement. Educational Research Review, 24, 10-30. DOI: $10.1016 / j$.edurev.2018.02.001

Bronfenbrenner, U. (1994). Ecological models of human development. Retrieved from http://www.psy.cmu.edu/ siegler/35bronfebrenner94.pdf 
Campbell, J. R., \& Verna, M. A. (2007). Effective parental influence: Academic home climate linked to children's achievement. Educational Research and Evaluation, 13(6), 501-519. DOI: $10.1080 / 13803610701785949$

Cohen, J. (1988). Statistical power analysis for the behavioral sciences (2nd ed.). Hillsdale, NJ: Erlbaum.

Coll, S. D., \& Coll, R. K. (2018). Using blended learning and out-of-school visits: pedagogies for effective science teaching in the twenty-first century. Research in Science and Technological Education, 36(2), 185-204. DOI: 10.1080/02635143.2017.1393658

Crowley, K., \& Callanan, M. (1998). Describing and supporting collaborative scientific thinking in parent-child interactions. Journal of Museum Education, 23(1), 12-17. DOI: 10.1080/10598650.1998.11510365

Çağdaş, A., Özel, E., \& Konca, A. S. (2016). İlkokul başlangıcında velilerin aile katılım düzeylerinin incelenmesi [Investigating parental involvement at beginning of elementary school]. Journal of Theory and Practice in Education, 12(4), 891-908.

Çelenk, S. (2003). Okul başarısının ön koşulu: Okul aile dayanışması [The Prerequisite for school success: Home-school cooperation]. İlkögretim Online, 2(2), 28-34.

Dabney, K. P., Chakraverty, D., \& Tai, R. H. (2013). The association of family influence and initial interest in science. Science Education, 97(3), 395-409. DOI: 10.1002/sce.21060

De Lurdes Cardoso, M. (2002). Studies of Portuguese and British primary pupils learning science through simple activities in the home. International Journal of Science Education, 24(1), 47-60. DOI: $10.1080 / 09500690110049079$

Desforges, C., \& Abouchaar, A. (2003). The impact of parental involvement, parental support and family education on pupil achievement and adjustment: A literature review. (Research Report No. RR433). Retrieved from https://www.nationalnumeracy.org.uk/sites/default/files/the_impact_of _parental_involvement.pdf

Dierking, L. D., \& Falk, J. H. (1994). Family behavior and learning in informal science settings: A review of the research. Science Education, 78(1), 57-72. DOI: 10.1002/sce.3730780104

Dierking, L. D., Falk, J. H., Rennie, L., Anderson, D., \& Ellenbogen, K. (2003). Policy statement of the "informal science education" ad hoc committee. Journal of Research in Science Teaching, 40(2), 108111. DOI: $10.1002 /$ tea. 10066

Dou, R., Hazari, Z., Dabney, K., Sonnert, G., \& Sadler, P. (2019). Early informal STEM experiences and STEM identity: The importance of talking science. Science Education, 103(3), 623-637. DOI: 10.1002/sce.21499

Eberbach, C., \& Crowley, K. (2017). From seeing to observing: How parents and children learn to see science in a botanical garden. Journal of the Learning Sciences, 26(4), 608-642. DOI: 10.1080/10508406.2017.1308867

Epstein, J. L. (1986). Parents' reactions to teacher practices of parent involvement. The Elementary School Journal, 86(3), 277-294. DOI: 10.1086/461449

Epstein, J. L. (2010). School/family/community partnerships: Caring for the children we share. Phi Delta Kappan, 92(3), 81-96. DOI: 10.1177/003172171009200326

Epstein, J. L., \& Dauber, S. L. (1991). School programs and teacher practices of parent involvement in inner-city elementary and middle schools. The Elementary School Journal, 91(3), 289-305. DOI: 10.1086/461656

Epstein, J. L., \& Salinas, K. C. (2004). Partnering with families and communities. Educational Leadership, 61(8), 12-19.

Erdoğan, Ç., \& Demirkasımoğlu, N. (2010). Ailelerin eğitim sürecine katılımına ilişkin öğretmen ve yönetici görüşleri [Teachers' and school administrators' views of parent involvement in education process]. Kuram ve Uygulamada Ĕ̈itim Yönetimi Dergisi, 16(3), 399-431.

Falk, J. H., \& Dierking, L. D. (2010). The 95 percent solution. American Scientist, 98(6), 486-493.

Fenichel, M., \& Schweingruber, H. A. (2010). Surrounded by science: Learning science in informal environments. Washington, DC: The National Research Council of National Academies Press.

Field, A. (2009). Discovering statistics using SPSS (3rd ed.). London: Sage.

Fleer, M. (1996). Fusing the boundaries between home and child care to support children's scientific learning. Research in Science Education, 26(2), 143-154. DOI: 10.1007/BF02356428

Fraenkel, J. R., Wallen, N. E., \& Hyun, H. H. (2012). How to design and evaluate research in education (8th ed.). New York: McGraw-Hill Education.

Fraser, B. J., \& Kahle, J. B. (2007). Classroom, home and peer environment influences on student outcomes in science and mathematics: An analysis of systemic reform data. International Journal of Science Education, 29(15), 1891-1909. DOI: 10.1080/09500690601167178

Gelmez-Burakgazi, S., \& Yildirim, A. (2014). Accessing science through media: Uses and gratifications among fourth and fifth graders for science learning. Science Communication, 36(2), 168-193. DOI: $10.1177 / 1075547013505847$ 
Gerber, B. L., Cavallo, A. M., \& Marek, E. A. (2001). Relationships among informal learning environments, teaching procedures and scientific reasoning ability. International Journal of Science Education, 23(5), 535-549. DOI: 10.1080/09500690116971

Gerber, B. L., Marek, E. A., \& Cavallo, A. M. (2001). Development of an informal learning opportunities assay. International Journal of Science Education, 23(6), 569-583. DOI: 10.1080/09500690116959

Gonzalez, L. M., Borders, L. D., Hines, E. M., Villalba, J. A., \& Henderson, A. (2013). Parental involvement in children's education: Considerations for school counselors working with Latino immigrant families. Professional School Counseling, 16(3), 185-193. DOI: 10.1177/2156759X1701600303

Goto, T., Nakanishi, K., \& Kano, K. (2018). A large-scale longitudinal survey of participation in scientific events with a focus on students' learning motivation for science: Antecedents and consequences. Learning and Individual Differences, 61, 181-187. DOI: 10.1016/j.lindif.2017.12.005

Green, C. L., Walker, J. M., Hoover-Dempsey, K. V., \& Sandler, H. M. (2007). Parents' motivations for involvement in children's education: An empirical test of a theoretical model of parental involvement. Journal of Educational Psychology, 99(3), 532-544. DOI: 10.1037/0022-0663.99.3.532

Hair, J. F., Black, W. C., Babin, B. J., \& Anderson, R. E. (2010). Multivariate data analysis (7th ed.). Upper Saddle River, NJ: Prentice Hall.

Halim, L., Abd Rahman, N., Zamri, R., \& Mohtar, L. (2018). The roles of parents in cultivating children's interest towards science learning and careers. Kasetsart Journal of Social Sciences, 39(2), 190-196. DOI: 10.1016/j.kjss.2017.05.001

Hall, R. L., \& Schaverien, L. (2001). Families' engagement with young children's science and technology learning at home. Science Education, 85(4), 454-481. DOI: 10.1002/sce.1018

Hamlin, D., \& Flessa, J. (2018). Parental involvement initiatives: An analysis. Educational Policy, 32(5), $697-$ 727. DOI: $10.1177 / 0895904816673739$

Harris, E., \& Winterbottom, M. (2018). 'Why do parrots talk?' co-investigation as a model for promoting family learning through conversation in a natural history gallery. Journal of Biological Education, 52(1), 89-100. DOI: $10.1080 / 00219266.2017 .1408934$

Hoover-Dempsey, K. V., \& Sandler, H. M. (1997). Why do parents become involved in their children's education? Review of Educational Research, 67(1), 3-42. DOI: 10.3102/00346543067001003

Hofstein, A., \& Rosenfeld, S. (1996). Bridging the gap between formal and informal science learning. Studies in Science Education, 28(1), 87-112. DOI: 10.1080/03057269608560085

Hornby, G., \& Lafaele, R. (2011). Barriers to parental involvement in education: An explanatory model. Educational Review, 63(1), 37-52. DOI: 10.1080/00131911.2010.488049

Hurley, K. D., Lambert, M. C., January, S. A. A., \& D'Angelo, J. H. (2017). Confirmatory factor analyses comparing parental involvement frameworks with secondary students. Psychology in the Schools, 54(9), 947-964. DOI: 10.1002/pits.22039

Jones, L. S. (1997). Opening doors with informal science: Exposure and access for our underserved students. Science Education, 81(6), 663-677.

Kasapoğlu, K. (2014). Facilitators and distractors of effective learning: Perceptions of middle school students, teachers and parents (Unpublished doctoral dissertation). Middle East Technical University, Ankara, Turkey.

Kaya, S., \& Lundeen, C. (2010). Capturing parents' individual and institutional interest toward involvement in science education. Journal of Science Teacher Education, 21(7), 825-841. DOI: 10.1007/s10972-0099173-4

Keçeli-Kaysili, B. (2008). Akademik başarının arttırılmasında aile katılımı [Parent involvement to improve academic achievement]. Ankara Üniversitesi Eğitim Bilimleri Fakültesi Özel Eğitim Dergisi, 9(1), 69-83.

Kim, M., \& Dopico, E. (2016). Science education through informal education. Cultural Studies of Science Education, 11(2), 439-445. DOI: 10.1007/s11422-014-9639-3

Koc, Y., Isiksal, M., \& Bulut, S. (2007). Elementary school curriculum reform in Turkey. International Education Journal, 8(1), 30-39.

Korpan, C. A., Bisanz, G. L., Bisanz, J., Boehme, C., \& Lynch, M. A. (1997). What did you learn outside of school today? Using structured interviews to document home and community activities related to science and technology. Science Education, 81(6), 651-662.

Lee, A. N., \& Nie, Y. (2015). The 'Why'and 'How'of engaging parents in their children's science learning in informal contexts: Theoretical perspectives and applications. In M. S. Khine (Ed.), Science Education in East Asia (pp. 93-121). Switzerland: Springer.

Leithwood, K., \& Patrician, P. (2015). Changing the educational culture of the home to increase student success at school. Societies, 5(3), 664-685. DOI: 10.3390/soc5030664

Lin, P. Y., \& Schunn, C. D. (2016). The dimensions and impact of informal science learning experiences on middle schoolers' attitudes and abilities in science. International Journal of Science Education, 38(17), 2551-2572. DOI: 10.1080/09500693.2016.1251631 
Maarschalk, J. (1988). Scientific literacy and informal science teaching. Journal of Research in Science Teaching, 25(2), 135-146. DOI: 10.1002/tea.3660250205

Ministry of National Education (2018). Fen Bilimleri dersi ögretim programı [Science education curriculum]. Retrieved from file:///C:/Users/Casper/Downloads/201812312311937FEN\%20B\%C4\%B0L\%C4\%B0M LER\%C4\%B0\%20\%C3\%96\%C4\%9ERET\%C4\%B0M\%20PROGRAMI2018.pdf

National Research Council (2012). A framework for k-12 science education: Practices, crosscutting concepts, and core ideas. Washington, D.C, USA: The National Academies Press.

Olgan, R. (2015). Influences on Turkish early childhood teachers' science teaching practices and the science content covered in the early years. Early Child Development and Care, 185(6), 926-942. DOI: $10.1080 / 03004430.2014 .967689$

Oswald, D. P., Zaidi, H. B., Cheatham, D. S., \& Brody, K. G. D. (2018). Correlates of parent involvement in students' learning: Examination of a national data set. Journal of Child and Family Studies, 27(1), 316323. DOI: $10.1007 / \mathrm{s} 10826-017-0876-4$

Özeke-Kocabaş, E. (2006). Eğitim sürecinde aile katılımı: Dünyada ve Türkiye'deki çalışmalar [Parent involvement in education: Studies in Turkey and in the world]. Türk Psikolojik Danışma ve Rehberlik Dergisi, 3(26), 143-153.

Renninger, K. A., \& Hidi, S. (2011). Revisiting the conceptualization, measurement, and generation of interest. Educational Psychologist, 46(3), 168-184. DOI: 10.1080/00461520.2011.587723

Rosenthal, S. (2018). Motivations to seek science videos on YouTube: free-choice learning in a connected society. International Journal of Science Education, 8(1), 22-39. DOI: 10.1080/21548455.2017.1371357

Ruxton, G. D., \& Beauchamp, G. (2008). Time for some a priori thinking about post hoc testing. Behavioral Ecology, 19(3), 690-693. DOI: 10.1093/beheco/arn020

Saçkes, M. (2014). How often do early childhood teachers teach science concepts? Determinants of the frequency of science teaching in kindergarten. European Early Childhood Education Research Journal, 22(2), 169-184. DOI: 10.1080/1350293X.2012.704305

Salmi, H., Thuneberg, H., \& Vainikainen, M. P. (2017). Making the invisible observable by Augmented Reality in informal science education context. International Journal of Science Education, Part B, 7(3), 253-268. DOI: $10.1080 / 21548455.2016 .1254358$

Saraç, H. (2017). Türkiye'de okul dışı öğrenme ortamlarına ilişkin yapılan araştırmalar: İçerik analizi çalışması [Researches related to outdoor learning environments in Turkey: Content analysis study]. Eğitim Kuram ve Uygulama Araştırmaları Dergisi, 3(2), 60-81.

Schermelleh-Engel, K., Moosbrugger, H., \& Müller, H. (2003). Evaluating the fit of structural equation models: Tests of significance and descriptive goodness-of-fit measures. Methods of Psychological Research Online, 8(2), 23-74.

Sha, L., Schunn, C., Bathgate, M., \& Ben-Eliyahu, A. (2016). Families support their children's success in science learning by influencing interest and self-efficacy. Journal of Research in Science Teaching, 53(3), 450472. DOI: $10.1002 /$ tea. 21251

Sun, D., \& Looi, C-K. (2018). Boundary interaction: Towards developing a mobile technology- enabled science curriculum to integrate learning in the informal spaces. British Journal of Educational Technology, 49(3), 505-515. DOI: $10.1111 /$ bjet.12555

Şentürk, E. (2015). Field trips to science centers: Teachers' perspectives, roles, and reflections (Unpublished doctoral dissertation). Middle East Technical University, Ankara, Turkey.

Tabachnick, B. G., \& Fidell, L. S. (2013). Using multivariate statistics (6th ed.). Boston: Pearson.

Vandermaas-Peeler, M., Mischka, M., \& Sands, K. (2019). "What do you notice?" Parent guidance of preschoolers' inquiry in activities at home. Early Child Development and Care, 189(2), 220-232. DOI: 10.1080/03004430.2017.1310724

Walker, J. M., Wilkins, A. S., Dallaire, J. R., Sandler, H. M., \& Hoover-Dempsey, K. V. (2005). Parental involvement: Model revision through scale development. The Elementary School Journal, 106(2), 85104. DOI: $10.1086 / 499193$

Worth, K. (2010). Science in early childhood classrooms: Content and process. Retrieved from http://ecrp.uiuc.edu/ beyond/seed/worth.html. 


\section{TÜRKÇE GENIŞLETILMIŞ ÖZET}

Okullar geleneksel olarak çocukların fen öğrenmelerinden sorumlu görülse de fen öğrenme süreci sadece okullarda gerçekleşmemektedir. Korpan, Bisanz, Bisanz, Boehme ve Lynch (1997) televizyon izleme, aile ile kitap okuma, toplum temelli programlara katılma, gözlemleme ve deney yapma gibi çeşitli okul dışı etkinliklerin çocukların fen öğrenmelerine yardımcı olduğuna dikkat çekmiştir. Gelmez-Burakgazi ve Yıldırım (2014) da Türkiye örnekleminde çocukların fen öğrenmek için internet, bilimsel dergiler ve televizyon gibi informal kaynaklardan destek aldıklarını göstermiştir. Alanyazın, çocukların okul dışında gerçekleşen informal fen etkinliklerinden daha çok keyif aldıklarını (Fenichel ve Schweingruber, 2010) ve informal fen etkinliklerinin çocukların fen öğrenme motivasyonunu arttırdığını (Goto, Nakanishi ve Kano, 2018) göstermektedir.

$\mathrm{Bu}$ çalışma, çocuklar için önemli informal fen öğrenme kaynaklarından birisine odaklanmaktadır: Aileler. Özellikle, bu araştırmada ailelerin okul dışında fen öğrenme için çocuklarına sağladıkları destek ele alınmıştır. Zira çocuklar, ailelerinin desteği ile doğayı gözlemleyebilir ve anlayabilirler (Eberbach ve Crowley, 2017). Bu çalışmada çocukların fen öğrenmesine yönelik aile desteği üç boyutta incelenmiştir: (a) çocukların fen öğrenmesini destekleyebilecek temel fen materyallerine ev ortamlarında erişim durumu, (b) ailelerin çocukları ile birlikte informal fen etkinliklerine katılım düzeyi ve (c) ailelerin çocuklarına temel fen konularını öğrenmelerine yönelik sundukları firsatların düzeyi. Önemli bir husus olarak, çocukların yaşının aile katılımı üzerindeki etkisi (Oswald, Zaidi, Cheatham ve Brody, 2018) göz önünde bulundurularak, okul öncesi, ilkokul (1.-4. sinıf) ve ortaokul (5.-8. sınıf) olmak üzere üç öğretim düzeyinde ailelerin çocuklarına fen öğrenmeleri için sundukları destek düzeyinde bir fark olup olmadığı araştırılmıştır. Bu çalışmanın üç temel nedenden dolayı önemli olduğu düşünülmektedir. Birincisi, etkili fen eğitimi için okul dışında öğrenme kritik bir öneme sahip olmasına rağmen eğitim araştırmalarında daha çok çocukların okul ortamında fen öğrenmelerine odaklanılmıştır (Gerber, Marek ve Cavallo, 2001; Fraser ve Kahle, 2007; Salmi, Thuneberg ve Vainikainen, 2017). Alanyazında çocukların okul dışında fen öğrenmelerine ilişkin aile desteği konusunda az sayıda çalışmaya rastlanılmaktadır (örneğin, Alexander, Johnson ve Kelley, 2012; Korpan ve diğerleri, 1997; Renninger ve Hidi, 2011). İkincisi, bu araştırma çocukların fen öğrenme sürecinde ailelerin sağladığı desteğe ilişkin ihtiyaçları ortaya koymaya katkı sağlayacaktır. $\mathrm{Bu}$ ihtiyaçların bilinmesi ile çocuklarının fen öğrenmelerini okul dışında desteklemeleri hususunda ailelere daha etkili rehberlik sağlanabilir. Son olarak, bu öncü nicel araştırma fen eğitimde aile desteğine ilişkin daha kapsamlı incelenmesi gereken faktörlere yönelik sonraki araştırmalara yol gösterebilir.

Bu çalışmada kesitsel tarama modeline başvurulmuştur. Veriler, Türkiye'nin kuzey bölgesindeki bir ilden toplanmıştır. Çalışmaya bu ilin merkez ilçelerindeki devlet okullarına devam eden okul öncesi, ilkokul (1.- 4. sınıf) ve ortaokul (5.- 8. sınıf) çocukları olan aileler dahil edilmiştir. Örneklem seçimi iki aşamada gerçekleştirilmiştir. İlk aşamada ailelere ulaşmak için okullar seçilmiştir. İkinci aşamada, seçilen okullarda her bir sınıf seviyesi için rastgele iki şube belirlenmiş ve bu şubelerdeki çocuklara ailelerine ulaştırmak üzere anket formları dağıtılmıştır. Bu çalışmada toplam 1392 aileye anket gönderilmiştir. Cevaplama oranı \%52,8'e karş1l1k gelerek, bu ailelerden 735'i anket formunu doldurmuştur. Araştırmaya katılan 735 ailenin \%53,7'sinin $(n=395)$ ilkokulda, \%32,8'nin $(n=241)$ ortaokulda ve \%13,5'inin $(n=99)$ okul öncesinde öğrenim görmekte olan çocuğu bulunmaktadır. Örneklemde katılımcıların çoğunluğunu anneler oluşturmaktadır $(\% 62,2)$. Katılımcıların \%39,6'sı bir yükseköğretim kurumundan mezun iken, \%20,3'ü ilkokul mezunu ya da ilkokul kademesinin altında bir eğitim düzeyine sahiptir. Veriler ilgili alanyazın incelenerek araştırmacılar tarafından geliştirilen aile anketi aracılı̆̆ıyla toplanmıştır. Anket maddelerinin geliştirilmesinde Alexander ve arkadaşlarının (2012), Olgan'ın (2015), Ulusal Araştırma Konseyi'nin (National Research Council, 2012) ve Saçkes'in (2014) çalışmalarından yararlanılmıştır. Anket iki fen eğitimi uzmanı, iki eğitim programı 
uzmanı ve çeşitli eğitim derecesine sahip altı aile tarafından gözden geçirilmiş ve iletilen geri bildirimler 1şı̆̆ında yeniden düzenlenmiştir. Aile anketi, ev ortamında bulunan fen materyalleri, ailelerin çocukları ile birlikte informal fen etkinliklerine katılım düzeyleri ve ailelerin temel fen konularına ilişkin olarak çocuklarına öğrenme fırsatı sunma düzeyleri olmak üzere üç bölümden oluşmaktadır. Anket için geçerlik ve güvenirlik kanıtları bulunmaktadır. Araştırma sorularına cevap vermek amaciyla betimleyici istatistiklere ve tek yönlü çok değişkenli varyans analizine (MANOVA) başvurulmuştur.

Oyuncak mıknatıslar okul öncesi, ilkokul ve ortaokul çocuklarının ev ortamlarında benzer şekilde en yüksek oranda bulunan materyal olarak ortaya çıkmıştır (Okul öncesi için \%71,8, İlkokul için \%63,9, Ortaokul için \%67,1). Okul öncesi, ilkokul ve ortaokul çocuklarının \%50'sinden fazlasının evinde termometre (Okul öncesi için \%63,5, İlkokul için \%54,4, Ortaokul için \%53,6) ve bilim ile ilgili basıl1 materyaller (Okul öncesi için \%54,1, İlkokul için \%54,4, Ortaokul için \%61,3) bulunduğu saptanmıştır. Okul öncesi $(\% 36,5)$ ve ilkokul $(\% 41,3)$ çocuklarının aksine, ortaokul çocuklarının yarısından fazlasının $(\% 51,8)$ bilim ile ilgili bilgisayar uygulamalarına evlerinde erişebildiği bulunmuştur. Teleskop, okul öncesi, ilkokul ve ortaokul çocuklarının evlerinde en düşük oranda bulunan materyal olarak tespit edilmiştir (Okul öncesi için \%4,7, İlkokul için \%3,2, Ortaokul için $\% 1,4)$. Ayrıca, aile raporlarına göre üç öğretim düzeyinde de çocukların \%50'sinden fazlasının evinde büyüteç, dürbün, pusula, oyuncak elektrik devresi, model/maket, bilim kitleri ve doğal materyal koleksiyonunun bulunmadığı ortaya çıkmıştır.

Üç öğretim düzeyinde de benzer şekilde ailelerin bilim gezilerine katılma boyutunda çocuklarını en düşük düzeyde destekledikleri ortaya çıkmıştır. Bu boyut için ortalama değerler her bir öğretim seviyesi için 5'lik cevaplama kategorisinde 2'nin altında bulunmuştur (Okul öncesi için Ort. = 1.92, $S S=0.80$, İlkokul için Ort. $=1.95, S S=0.75$, Ortaokul için $O r t .=1.91, S S=0.82)$. Fen öğrenmek için kaynak kullanımına yönelik aile desteği boyutuna ilişkin ortalamalar her üç öğretim seviyesinde 5'lik cevaplama kategorisinde 3'e yakın bulunmuştur (Okul öncesi için Ort. $=2.75, S S=0.79$, İlkokul için Ort. $=2.77, S S=0.81$, Ortaokul için Ort. $=2.86, S S=0.76$ ). Çocukların fen ve doğa etkinlikleri yapmasına yönelik aile desteğine ilişkin olarak, ortaokul çocuklarının ailelerinin ortalama değeri 3'e yakın bulunurken $($ Ort. $=2.78, S S=0.85)$, bu boyuta ait ortalama değerlerin okul öncesi ve ilkokul çocuklarının aileleri için 3'ü biraz geçtiği tespit edilmiştir (Okul öncesi için Ort. $=3.21, S S=0.70$, İlkokul için Ort. $=3.03, S S=0.83$ ). Okul öncesi ve ilkokul çocukları için fen ve doğa etkinlikleri yapma boyutuna ilişkin aile desteği, fen öğrenmek için kaynak kullanımı boyutuna ilişkin aile desteğinden daha yüksek bulunmuştur. Ancak ortaokul çocuklarının ailelerinin, fen ve doğa etkinlikleri yapmaya kıyasla fen öğrenimi için kaynakları kullanmaya yönelik olarak çocuklarına daha fazla firsat sundukları belirlenmiştir.

İlk MANOVA sonuçları, ailelerin çocuklarına informal fen etkinliklerine katılmaya yönelik sundukları firsatlarla ilgili üç bağımlı değişkenin doğrusal kombinasyonu üzerinde öğretim seviyesinin önemli bir etkisinin olduğunu göstermiştir: $F(6,1404)=2737.65, p=.000$; Wilks' Lambda $=.93$. Kısmi eta kare değeri, öğretim seviyesi tarafindan örneklemde açılanan varyansın $\% 4$ olduğunu ortaya koymuştur. Üç bağımlı değişken için sonuçlar ayrı ayrı incelendiğinde, bulgular öğretim seviyesinin ailelerin fen ve doğa etkinlikleri yapmak için çocuklarına sundukları fırsatların düzeyini önemli bir şekilde etkilediğini göstermiştir $(F(2,704)=10.999, p=.000$, kısmi eta kare değeri $=.03)$. Scheffe post hoc testi yöntemiyle ortaokul çocuklarının ailelerinin okul öncesi ve ilkokul çocuklarının ailelerine kıyasla fen ve doğa etkinlikleri yapma boyutunda çocuklarına önemli ölçüde daha düşük düzeyde destek oldukları tespit edilmiştir. İkinci MANOVA sonuçları, öğretim seviyesinin ailelerin temel fen konularını öğrenmelerine yönelik çocuklarına sundukları fırsatlarla ilgili iki bağımlı değişkenin kombinasyonunu önemli ölçüde etkilediğini göstermiş̧ir $(F(4,1340)=3.952, p=.003$; Wilks' Lambda $=.98)$. Kısmi eta kare değerine göre öğretim seviyesi örneklemdeki varyansın \%1'ini açıklamıştır. Öğretim seviyesinin her iki bağımlı değişken üzerindeki etkisinin önemli olduğu bulunmuştur: Madde, enerji ve canlılar ile ilgili konular için $F(2,671)=5.434, p=.005$, kısmi eta kare değeri $=.02$; Gökyüzü ile ilgili konular için $F(2,671)=7.518, p=.001$, k1smi eta kare değeri $=$ .02. Scheffe post hoc yöntemi ile yapılan çoklu karşılaştırmalar, okul öncesi çocuklarının ailelerinin 
ortaokul çocuklarının ailelerine kıyasla madde, enerji ve canlılar ile ilgili fen konularını öğrenmelerine yönelik çocuklarına önemli ölçüde daha fazla firsat sunduklarını göstermiştir. Ayrıca, okul öncesi dönemdeki çocuklara gökyüzü ile ilgili fen konularını öğrenmelerine yönelik sunulan aile desteği, ilkokul ve ortaokul çocuklarına sağlanan aile desteğinden anlamlı düzeyde daha yüksek bulunmuştur.

Bu bulgular okul dışında çocukların fen öğrenmeleri hususunda aile desteğinin geliştirilmesine yönelik bir ihtiyaç olduğunu göstermektedir. Özellikle ortaokul çocuklarının informal fen eğitiminde aile desteği daha yakından incelenmelidir. Çocuklarının eğitimindeki rollerine ilişkin aile inançları, çocuklarına yardımcı olma konusundaki aile öz yeterlik algısı ve hem çocuğun hem okulun aile katılımına ilişkin görüşlerine yönelik aile inançları ailelerin çocuklarının eğitimine katılım konusundaki kararlarını etkileyebilmektedir (Hoover-Dempsey ve Sandler, 1997; Walker, Wilkins, Dallaire, Sandler ve Hoover-Dempsey, 2005). Özellikle Türkiye'de eğitimde aile katılımının düşük seviyede olması (a) ailelerin çocuklarının eğitiminden öncelikle okulları sorumlu tutmaları, (b) ailelerin çocuklarının eğitimine nasıl katılacakları konusunda bilinçli olmamaları ve (c) öğretmenlerin ve okul yöneticilerinin eğitim sürecine ailelerin katılımını sağlamak için fazla çaba göstermemeleri ile açıklanabilir (Erdoğan ve Demirkasımoğlu, 2010). Ayrıca Türkiye'de aileler, çocuklarının zaten etkili bir şekilde öğrendiklerini düşündükleri ve çocukları ortaokulda öğrenim gördüğü için aile katılımını gerekli görmüyor olabilirler (Kasapoğlu, 2014). Çocukların okul dışı öğrenme firsatlarından yoksun kalmamaları için öncelikli olarak bu konuda aile farkındalığı geliştirilmelidir (Lee ve Nie, 2015). Bu amaç doğrultusunda, öğretmenler ve okullar, aileleri evde neler yapabilecekleri hakkında yönlendirmeliler (Epstein, 1986; Leithwood ve Patrician, 2015) ve iyi tasarlanmış aile ve toplum iş birliği programları oluşturmalılardır (Epstein ve Salinas, 2004). Bu programlar özellikle ailelerin çocuklarının fen öğrenmelerini desteklemeye yönelik yeterlik algılarının gelişmesine yardımcı olmalı ve ailelerin çocuklarının eğitimine katılmaya yönelik ilgisini artırmalıdır (Kaya ve Lundeen, 2010). Bu programlarda aynı zamanda Fen Bilimlerinin mutlaka özel araç-gereç gerektiren bir laboratuvar disiplini olmadığına ve aslında günlük yaşamın bir parçası olduğuna dikkat çekilmelidir (Fleer, 1996). 